\title{
Front Matter: Volume 10366
}

, "Front Matter: Volume 10366," Proc. SPIE 10366, Hybrid Memory Devices and Printed Circuits 2017, 1036601 (2 November 2017); doi:

$10.1117 / 12.2297129$

SPIE Event: SPIE Organic Photonics + Electronics, 2017, San Diego, California, SPIE. United States 


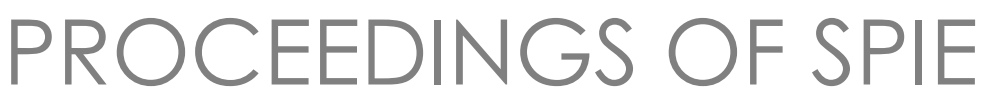

\title{
Hybrid Memory Devices and Printed Circuits 2017
}

\author{
Emil J. W. List-Kratochvil \\ Editor
}

10 August 2017

San Diego, California, United States

Sponsored by

SPIE

Cosponsored by

Kolon Industries, Inc. (Korea, Republic of)

Published by

SPIE 
The papers in this volume were part of the technical conference cited on the cover and title page. Papers were selected and subject to review by the editors and conference program committee. Some conference presentations may not be available for publication. Additional papers and presentation recordings may be available online in the SPIE Digital Library at SPIEDigitalLibrary.org.

The papers reflect the work and thoughts of the authors and are published herein as submitted. The publisher is not responsible for the validity of the information or for any outcomes resulting from reliance thereon.

Please use the following format to cite material from these proceedings:

Author(s), "Title of Paper," in Hybrid Memory Devices and Printed Circuits 2017, edited by Emil J. W. List-Kratochvil, Proceedings of SPIE Vol. 10366 (SPIE, Bellingham, WA, 2017) Seven-digit Article CID Number.

ISSN: 0277-786X

ISSN: 1996-756X (electronic)

ISBN: 9781510611894

ISBN: 9781510611900 (electronic)

Published by

SPIE

P.O. Box 10, Bellingham, Washington 98227-0010 USA

Telephone +1 3606763290 (Pacific Time) · Fax +1 3606471445

SPIE.org

Copyright @ 2017 , Society of Photo-Optical Instrumentation Engineers.

Copying of material in this book for internal or personal use, or for the internal or personal use of specific clients, beyond the fair use provisions granted by the U.S. Copyright Law is authorized by SPIE subject to payment of copying fees. The Transactional Reporting Service base fee for this volume is $\$ 18.00$ per article (or portion thereof), which should be paid directly to the Copyright Clearance Center (CCC), 222 Rosewood Drive, Danvers, MA 01923. Payment may also be made electronically through CCC Online at copyright.com. Other copying for republication, resale, advertising or promotion, or any form of systematic or multiple reproduction of any material in this book is prohibited except with permission in writing from the publisher. The CCC fee code is 0277 $786 \times / 17 / \$ 18.00$.

Printed in the United States of America.

Publication of record for individual papers is online in the SPIE Digital Library.

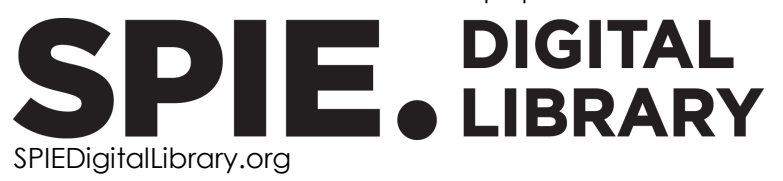

Paper Numbering: Proceedings of SPIE follow an e-First publication model. A unique citation identifier (CID) number is assigned to each article at the time of publication. Utilization of CIDs allows articles to be fully citable as soon as they are published online, and connects the same identifier to all online and print versions of the publication. SPIE uses a seven-digit CID article numbering system structured as follows:

- The first five digits correspond to the SPIE volume number.

- The last two digits indicate publication order within the volume using a Base 36 numbering system employing both numerals and letters. These two-number sets start with $00,01,02,03$, 04, 05, 06, 07, 08, 09, 0A, OB ... 0Z, followed by 10-1Z, 20-2Z, etc. The CID Number appears on each page of the manuscript. 


\title{
Contents
}

\author{
$\checkmark$ Authors \\ vii Conference Committee
}

\section{LARGE AREA PRINTED ELECTRONIC DEVICES}

10366 OC Methods for fabrication of flexible hybrid electronics (Invited Paper) [10366-12]

10366 OD Printed soft-electronics for remote body monitoring (Invited Paper) [10366-13] 
Proc. of SPIE Vol. 10366 1036601-4

Downloaded From: https://www.spiedigitallibrary.org/conference-proceedings-of-spie on 26 Apr 2023 Terms of Use: https://www.spiedigitallibrary.org/terms-of-use 


\section{Authors}

Numbers in the index correspond to the last two digits of the seven-digit citation identifier (CID) article numbering system used in Proceedings of SPIE. The first five digits reflect the volume number. Base 36 numbering is employed for the last two digits and indicates the order of articles within the volume. Numbers start with 00, 01, 02, 03, 04, 05, 06, 07, 08, 09, OA, OB...0Z, followed by 10-1Z, 20-2Z, etc.

Doris, Sean E., OC

Jeihani, Vala, OD

Kor, Siv, OC

Krusor, Brent, OC

Mantysalo, Matti, OD

Mei, Ping, OC

Pierre, Adrien, OC

Ready, Steve E., OC

Russo, Beverly, OC

Schwartz, David E., OC

Street, Robert A., OC

Vehkaoja, Antti, OD

Veres, Janos, OC

Vuorinen, Tiina, OD

Zhang, Yong, OC 
Proc. of SPIE Vol. 10366 1036601-6

Downloaded From: https://www.spiedigitallibrary.org/conference-proceedings-of-spie on 26 Apr 2023 Terms of Use: https://www.spiedigitallibrary.org/terms-of-use 


\title{
Conference Committee
}

\author{
Symposium Chairs
}

Zakya H. Kafafi, Lehigh University (United States)

Ifor D. W. Samuel, University of St. Andrews (United Kingdom)

Conference Chair

Emil J. W. List-Kratochvil, Humboldt-Universität zu Berlin (Germany)

Conference Program Committee

Paul W. M. Blom, Max-Planck-Institut für Polymerforschung (Germany)

Wen-Chang Chen, National Taiwan University (Taiwan)

Norbert Koch, Humboldt-Universität zu Berlin (Germany)

Jang-Sik Lee, Pohang University of Science and Technology

(Korea, Republic of)

Tae-Woo Lee, Pohang University of Science and Technology

(Korea, Republic of)

Tse Nga Ng, University of California, San Diego (United States)

Ronald Österbacka, Åbo Akademi University (Finland)

Barbara Stadlober, JOANNEUM RESEARCH Forschungsgesellschaft

$\mathrm{mbH}$ (Austria)

Arul Lenus Roy Vellaisamy, City University of Hong Kong

(Hong Kong, China)

Fei Zeng, Tsinghua University (China)

Session Chairs

1 Neuromorphic Devices and Hybrid Memories

Emil J. W. List-Kratochvil, Humboldt-Universität zu Berlin (Germany)

2 Hybrid Memories

Ana Claudia Arias, University of California, Berkeley (United States)

3 Large Area Printed Electronic Devices

Ho Won Jang, Seoul National University (Korea, Republic of)

4 Memories and Printed Devices

Uli Lemmer, Karlsruher Institut für Technologie (Germany) 
Proc. of SPIE Vol. 10366 1036601-8

Downloaded From: https://www.spiedigitallibrary.org/conference-proceedings-of-spie on 26 Apr 2023 Terms of Use: https://www.spiedigitallibrary.org/terms-of-use 